\title{
SISTEM INFORMASI PENJADWALAN DAN PENGENDALIAN BIAYA PROYEK KONSTRUKSI
}

\author{
Maksum Tanubrata ${ }^{1}$, Marco Dirgahadi Lukman ${ }^{2}$ \\ ${ }^{1}$ Dosen Tetap, Jurusan Teknik Sipil, Fakultas Teknik, Universitas Kristen Maranatha \\ ${ }^{2}$ Mahasiswa, Jurusan Teknik Sipil, Fakultas Teknik, Universitas Kristen Maranatha \\ Jl.Prof.drg.Suria Sumantri MPH. No. 65 Bandung 40164
}

\begin{abstract}
ABSTRAK
Seiring dengan semakin berkembangnya zaman pada saat ini dapat mempengaruhi dalam bidang teknologi dan sistem informasi yang telah berkembang pesat sehingga perusahaan dituntut agar dapat terus memperbaiki kinerja sehingga tetap bertahan dalam ketatnya persaingan global yang terjadi di Indonesia saat ini. Salah satu cara yang dapat ditempuh oleh perusahaan dalam memperbaiki kinerja adalah dengan menggunakan sebuah teknologi dan sistem informasi yang dapat mempermudah dalam aliran data sehingga beban pekerjaan menjadi berkurang dan proses pengolahan data menjadi lebih efektif dan efisien. Persaingan yang terjadi mencakup segala bidang perusahaan termasuk perusahaan yang bergerak di bidang konstruksi. Dalam bidang konstruksi penjadwalan dan pengendalian proyek merupakan salah satu elemen penting karena berkaitan dengan waktu dan biaya. Penjadwalan dan pengendalian proyek yang buruk seringkali mengakibatkan keterlambatan penyelesaian proyek konstruksi sipil. Baik dari penentuan waktu yang dibutuhkan untuk menyelesaikan suatu pekerjaan maupun kurang terpantaunya kemajuan proyek. Oleh karena itu, diperlukan bantuan dari bidang ilmu lain untuk membantu penyusunan jadwal proyek dan pemantauan kemajuan proyek. Salah satunya adalah dengan pembuatan sistem informasi terhadap penjadwalan dan pengendalian proyek. Waktu dan biaya merupakan salah satu aspek yang penting dalam suatu proyek konstruksi. Biaya proyek yang diterima harus sesuai dengan kebutuhan dalam kemajuan proyek karena hal ini dapat menentukan keberhasilan proyek. Untuk itu diperlukan adanya penjadwalan dan pengendalian biaya yang baik. Sehingga tingkat keterlambatan dan kurangnya biaya dapat diminimalisasi atau bahkan dihindari.
\end{abstract}

Kata kunci : konstruksi, jadwal, kendali, sistem, informasi

\begin{abstract}
Along with the development at this age may affect the field of technology and information systems has grown rapidly so that the company is required in order to continue to improve performance so that it remains survive in global competition is happening in Indonesia at this time. One way that can be taken by the company in improving performance is to use a technology and information systems that can facilitate the flow of data so that the workload is reduced and data processing become more effective and efficient. Competition happens covers all areas of the company, including companies engaged in the construction sector. In the field of construction scheduling and project control is one important element as it pertains to time and cost. Scheduling and control of bad projects often result in delays in completion of civil construction projects. Both of determining the time required to complete a job or less terpantaunya progress of the project. There fore, the necessary assistance from other disciplines to assist the preparation of project schedules and a monitoring project progress. One of them is by making the information system of scheduling and project control. Time and cost is one important aspect of a construction project. Project costs must be received in accordance with the requirements in the progress of the project as this can determine the success of the project. It required a scheduling and cost control is good. So that the level a delay and lack of cost can be minimized or even avoided.
\end{abstract}

Keywords: construction, schedules, controls, systems, information. 


\section{PENDAHULUAN}

\subsection{Perumusan Masalah}

Rumusan masalah sebagai berikut:

1. Bagaimana mengatasi keterlambatan penyelesaian proyek konstruksi ?

2. Bagaimana mengelola arus pengeluaran biaya proyek ?

3. Bagaimana sistem informasi yang tepat untuk mengatasi masalah tersebut ?

\subsection{Maksud dan Tujuan}

Adapun maksud dan tujuan dari makalah ini antara lain:

1. Membuat penjadwalan proyek konstruksi dengan penggunaan metode Bar Chart dan Kurva S.

2. Menghitung pengeluaran biaya proyek berdasarkan penjadwalan proyek konstrusi.

3. Untuk membuktikan manfaat sistem informasi dalam mengatasi masalah pengendalian proyek dalam perusahaan konstruksi.

\subsection{Batasan Masalah}

Sistem Informasi yang direncanakan hanya terbatas untuk menghasilkan penjadwalan dan pengendalian proyek pada sub-pekerjaan tertentu. Penjadwalan yang dihasilkan berupa Bar Chart dan Kurva S. Pengendalian biaya proyek dilakukan berdasarkan hubungan antara presentase bobot pekerjaan per minggu dengan biaya proyek.

\subsection{Penjadwalan Proyek}

Penjadwalan proyek merupakan salah satu elemen hasil perencanaan, yang dapat memberikan informasi tentang jadwal rencana dan kemajuan proyek dalam hal kinerja sumber daya berupa biaya, tenaga kerja, peralatan dan material serta rencana durasi proyek dan progres waktu untuk penyelesaian proyek. Dalam proses penjadwalan, penyusunan kegiatan dan hubungan antarkegiatan dibuat lebih terperinci dan sangat detail. Hal ini dimaksudkan untuk membantu pelaksanaan evaluasi proyek. Penjadwalan adalah pengalokasian waktu yang tersedia untuk melaksanakan masing-masing pekerjaan dalam rangka menyelesaikan suatu proyek hingga tercapai hasil optimal dengan mempertimbangkan keterbatasan-keterbatasan yang ada. 


\section{TINJAUAN LITERATUR}

\subsection{Pengendalian Proyek}

Pengendalian proyek berjalan sepanjang daur hidup proyek guna mewujudkan performa yang baik di dalam setiap tahap. Perencanaan dibuat sebagai bahan acuan bagi pelaksanaan pekerjaan. Bahan Acuan tersebut selanjutnya akan menjadi standar pelaksanaan pada proyek yang bersangkutan, meliputi spesifikasi teknik, jadwal, dan anggaran. Pemantauan harus dilakukan selama masa pelaksanaan proyek untuk mengetahui prestasi dan kemajuan yang telah dicapai. Informasi hasil pemantauan ini berguna sebagai bahan evaluasi performa yang telah dicapai pada saat pelaporan.

\subsection{Pengeluaran proyek}

Proyeksi dari pendapatan dan pengeluaran selama umur proyek dapat dikembangkan dari penjadwalan proyek yang digunakan kontraktor. Pada kebanyakan kontrak, owner seringkali meminta kontraktor untuk menyediakan kurva S dari pekerjaan dan biaya terhadap umur proyek. Kontraktor membuat barchart proyek, kemudian setelah didapat prestasi dan prestasi kumulatif dihitung pengeluaran per bulan atau per minggu dengan mengalikan nilai proyek secara kesuluruhan dengan presentase prestasi yang dicapai per bulan atau per minggu.

\subsection{Bar Chart (Bagan Balok)}

Bagan balok dapat dibuat secara manual atau dengan menggunakan komputer. Bagan ini tersusun pada koordinat X dan Y. Pada sumbu tegak lurus X, dicatat pekerjaan atau elemen atau paket kerja dari hasil penguraian lingkup suatu proyek, dan digambar sebagai balok. Sedangkan pada sumbu horizontal Y, tetulis satuan waktu, misalnya hari, minggu atau bulan. Di sini, waktu mulai dan waktu akhir masing-masing pekerjaan adalah ujung kiri dan kanan dari balok-balok yang bersangkutan. Pada waktu membuat bagan balok telah diperhatikan urutan kegiatan, meskipun belum terlihat hubungan ketergantungan antara satu dengan yang lain. Format perkiraan urutan pekerjaan, skala waktu dan analisis kemajuan pekerjaan pada saat pelaporan.

\subsection{Kurva S}

Kurva S adalah sebuah grafik yang dikembangkan oleh Warren T. ..Kurva S dapat menujukkan kemajuan proyek bedasarkan kegiatan, waktu dan bobot pekerjaan yang direpresentasikan sebagai persentasi kumulatif dari seluruh kegiatan proyek. Visualisasi kurva S dapat memberikan informasi mengenai kemajuan proyek dengan 
membandingkannya terhadap jadwal rencana. Dari sini dapat diketahui apakah ada keterlambatan atau percepatan proyek. Indikasi tersebut dapat menjadi informasi awal guna melakukan tindakan koreksi dalam proses pengendalian jadwal. urva S sangat bermanfaat untuk dipakai sebagai laporan bulanan dan laporan kepada pimpinan proyek maupun pimpinan perusahaan karena kurva ini dapat dengan jelas menunjukkan kemajuan proyek dalam bentuk yang mudah dipahami.

\section{RANCANGAN APLIKASI}

\subsection{Desain Antar Muka}

Sistem informasi penjadwalan proyek ini terdiri dari 3 form yaitu Main Form (Halaman utama), Form Pekerjaan, dan Form Diagram Balok. Rancangan masing-masing form adalah sebagai berikut :

\subsection{Halaman Utama}

Halaman utama terdiri dari 3 tombol, yaitu Pekerjaan, Proyek, dan Diagram Balok. Tombol Pekerjaan berfungsi untuk membuka form pekerjaan yang merupakan halaman untuk menginput data pekerjaan.

Tombol Proyek berfungsi untuk membuka form proyek yang merupakan halaman untuk menginput data proyek. Sedangkan tombol diagram untuk membuka form diagram balok yang merupakan halaman untuk mengeksekusi data pekerjaan.

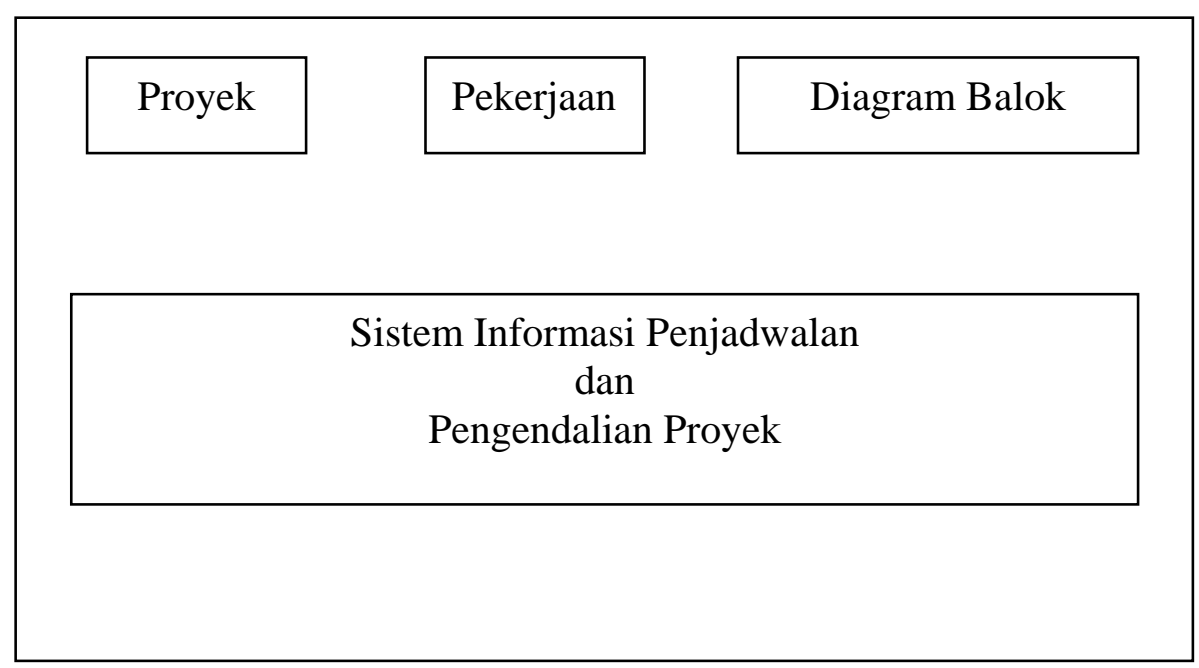

Gambar 1. Sistem informasi Penjadwalan dan Pengendalian Proyek. 


\subsection{Halaman Proyek}

Halaman proyek terdiri dari 3 tombol, yaitu Add, Edit, dan Delete, serta 1 buah tabel data proyek. Tombol Add berfungsi untuk menambahkan data kedalam tabel proyek. Tombol Edit berfungsi untuk mengubah data yang telah diinput kedalam tabel proyek sebelumnya. Sedangkan tombol delete berfungsi untuk menghapus data proyek yang telah diinput sebelumnya.

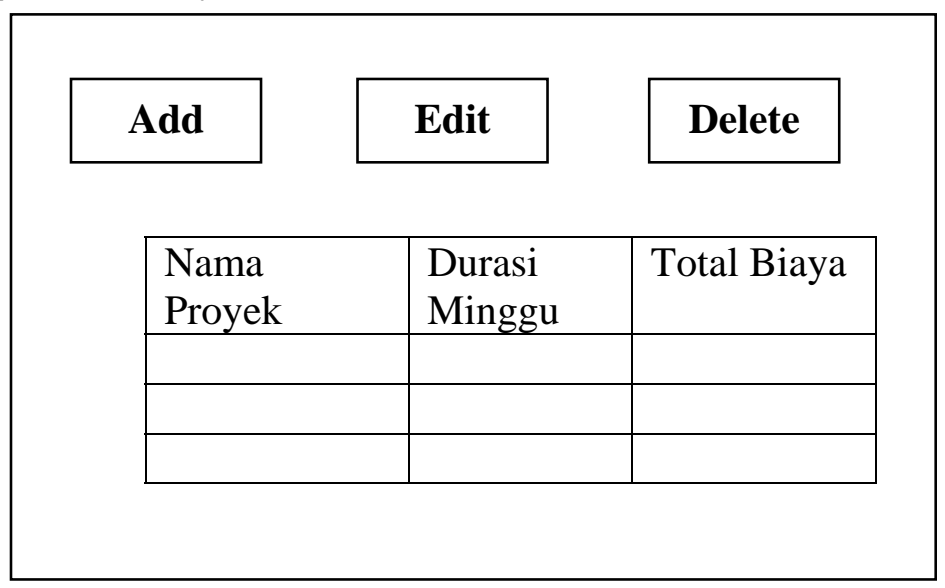

\section{Gambar 2 Rancangan Form Proyek.}

\subsection{Halaman Pekerjaan}

Halaman pekerjaan terdiri dari 1 textbox yang berupa keterangan nama proyek, selain itu halaman ini juga terdiri dari 3 tombol, yaitu Add, Edit, dan Delete, serta 1 buah tabel data pekerjaan. Tombol Add berfungsi untuk menambahkan data kedalam tabel pekerjaan. Tombol Edit berfungsi untuk mengubah data yang telah diinput kedalam tabel pekerjaan sebelumnya. Sedangkan tombol delete berfungsi untuk menghapus data pekerjaan yang telah diinput sebelumnya.

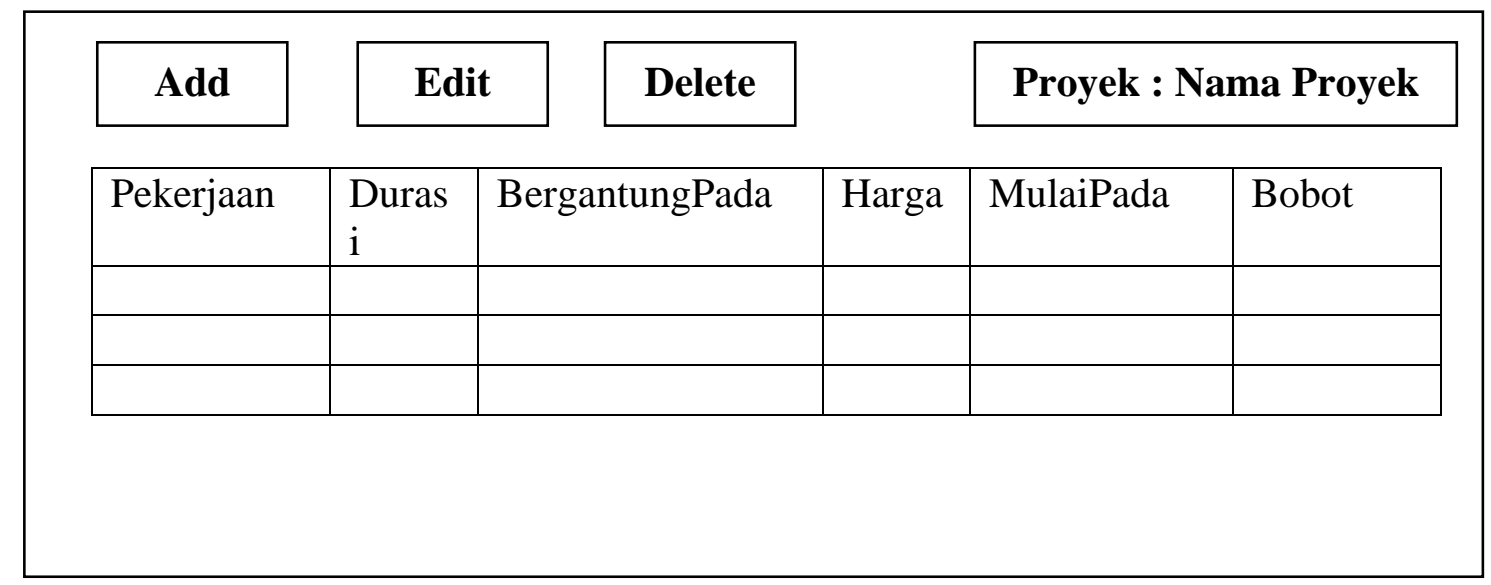

Gambar 3 Rancangan Form Pekerjaan. 


\subsection{Halaman Diagram Balok}

Halaman diagram balok terdiri dari 1 tombol, yaitu tombol create, 1 buah panel, serta tabel data pekerjaan. Tombol Create berfungsi untuk mengeksekusi data pekerjaan yang telah diinput sebelumnya pada halaman pekerjaan. Panel merupakan tempat yang akan menampilkan diagram balok dan kurva S setelah tombol create ditekan dan dieksekusi. Kemudian dibawah panel tersebut akan muncul label yang menunjukkan prestasi, prestasi kumulatif, dan biaya pengeluaran. Sedangkan tabel pekerjaan merupakan tampilan dari data pekerjaan yang telah diinput pada halaman pekerjaan.

\begin{tabular}{|c|c|c|c|c|c|c|c|c|c|c|c|c|}
\hline \multicolumn{13}{|l|}{ Create } \\
\hline \multirow[t]{4}{*}{$\begin{array}{l}\text { Pekerj } \\
\text { aan }\end{array}$} & $\begin{array}{l}\mathrm{Bl} \\
\mathrm{n} 1 \\
\end{array}$ & $\begin{array}{l}\mathrm{Bl} \\
\mathrm{n} 2\end{array}$ & $\begin{array}{l}\mathrm{Bl} \\
\mathrm{n} 3\end{array}$ & $\begin{array}{l}\mathrm{Bl} \\
\mathrm{n} 4 \\
\end{array}$ & $\begin{array}{l}\mathrm{Bl} \\
\mathrm{n} 5\end{array}$ & $\begin{array}{l}\mathrm{Bl} \\
\mathrm{n} 6\end{array}$ & $\begin{array}{l}\mathrm{Bl} \\
\mathrm{n} 7\end{array}$ & $\begin{array}{l}\mathrm{Bl} \\
\mathrm{n} 8 \\
\end{array}$ & $\begin{array}{l}\mathrm{Bl} \\
\mathrm{n} 9\end{array}$ & $\begin{array}{l}\text { Bln } \\
10 \\
\end{array}$ & $\begin{array}{l}\text { Bln } \\
11\end{array}$ & $\begin{array}{l}\text { Bln } \\
12 \\
\end{array}$ \\
\hline & & & & & & & & & & & & \\
\hline & & & & & & & & & & & & \\
\hline & & & & & & & & & & & & \\
\hline \multicolumn{2}{|l|}{ Prestasi } & & & & & & & & & & & \\
\hline \multicolumn{13}{|c|}{$\begin{array}{l}\text { Prestasi } \\
\text { Kumulatif }\end{array}$} \\
\hline \multicolumn{13}{|l|}{ biaya } \\
\hline Pekerja & & $\begin{array}{l}\mathrm{Du} \\
\mathrm{i}\end{array}$ & & Berg & ntun & gPada & & Harga & $\mathrm{Mu}$ & aiPada & & Bobot \\
\hline & & & & & & & & & & & & \\
\hline & & & & & & & & & & & & \\
\hline
\end{tabular}

Gambar 4 Rancangan Form Diagram Balok.

\section{HASIL TERCAPAI}

Dalam Sistem Informasi Penjadwalan dan Pengendalian Proyek ini terdapat beberapa form, yaitu : Main Form, Form Proyek, Form Pekerjaan, dan Form Diagram Balok. Form-form tersebut akan dievaluasi secara umum berdasarkan hasil yang telah dicapai.

\subsection{Main Form}

Main Form merupakan halaman utama yang pertama kali muncul ketika aplikasi ini dieksekusi. Dalam halaman ini terdapat tiga tombol, yaitu tombol Proyek, tombol Pekerjaan dan tombol Diagram Balok. Tombol Proyek berfungsi untuk membuka Form 
Proyek. Tombol pekerjaan berfungsi untuk membuka Form Pekerjaan sedangkan tombol Diagram berfungsi untuk membuka Form Diagram Balok.

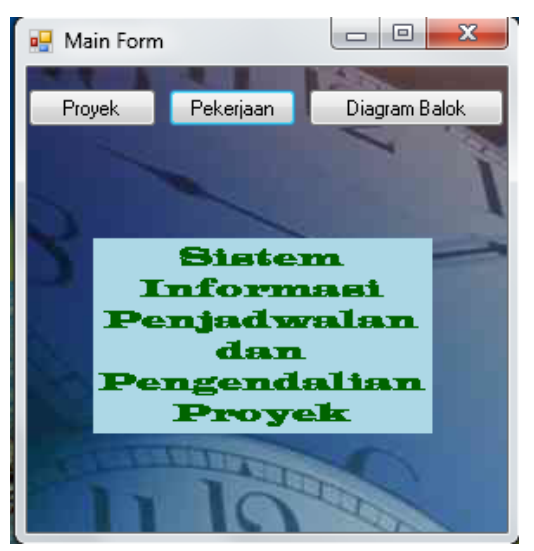

Gambar 5 Main Form.

\subsection{Form Proyek}

Form Proyek akan terbuka setelah mengklik tombol proyek. Form ini berisi tombol Add, tombol Edit, dan tombol Delete, serta tabel proyek yang berisi Nama Proyek, Durasi, dan Total Biaya.

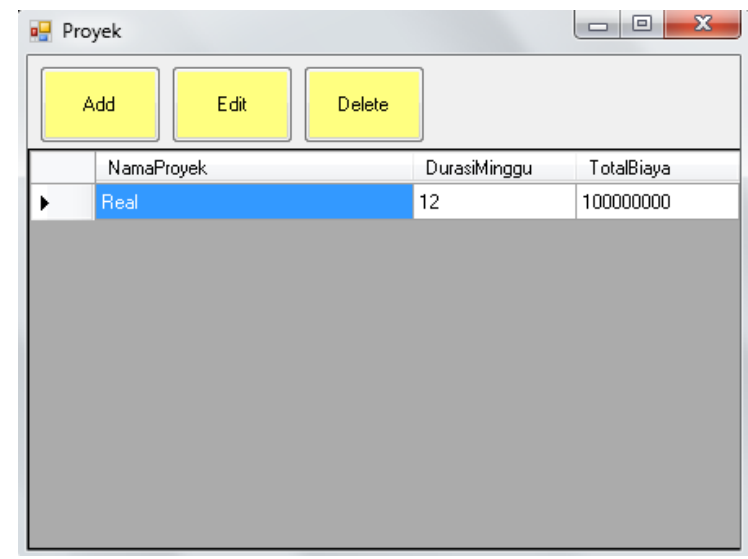

Gambar 6 Form Proyek.

\subsubsection{Tombol Add}

Apabila tombol Add ditekan maka akan muncul group box untuk menginput data-data proyek, seperti yang tertera pada gambar berikut : 


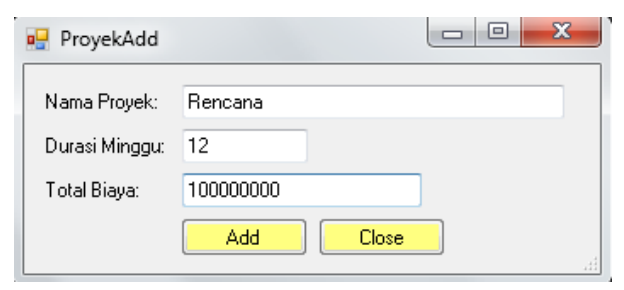

Gambar 7 Group Box Add.

Pada Group Box Add ini dapat dilakukan penginputan data proyek, antara lain data nama Proyek, Durasi Minggu, dan Total Biaya. Selain itu terdapat pula tombol Add dan tombol Close. Tombol Add berfungsi untuk menambahkan data dan menyimpannya ke database. Tombol Close berfungsi untuk menutup group box.

\subsubsection{Tombol Edit}

Apabila tombol Edit ditekan maka akan muncul group box untuk mengedit datadata proyek, seperti yang tertera pada gambar berikut :

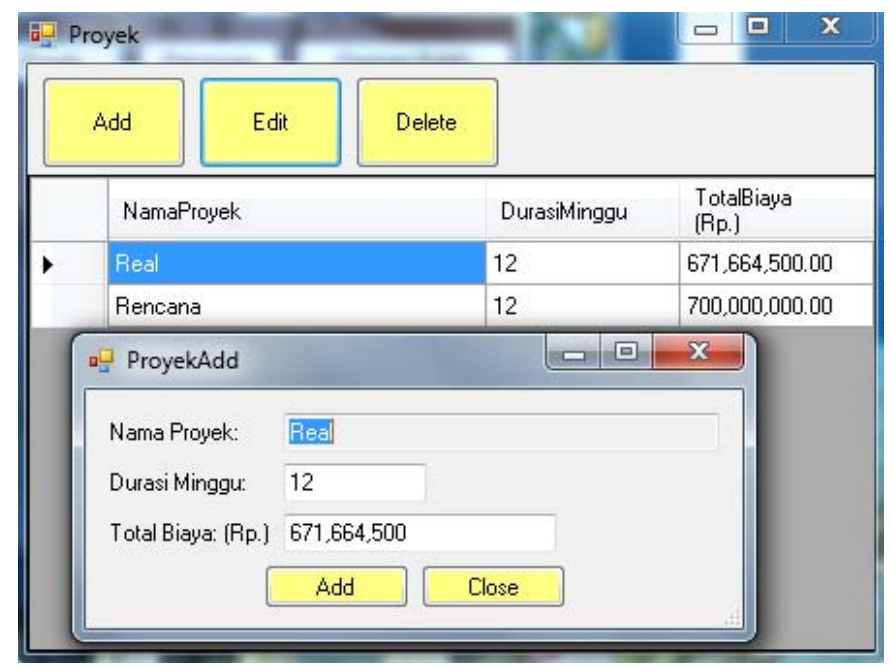

Gambar 8 Group Box Edit.

Pada Group Box Edit ini dapat dilakukan pengubahan data proyek yang telah diinput, antara lain data nama Proyek, Durasi Minggu, dan Total Biaya. Selain itu terdapat pula tombol Add dan tombol Close. Tombol Add berfungsi untuk mengubah data dan menyimpannya ke database. Tombol Close berfungsi untuk menutup group box.

\subsubsection{Tombol Delete}

Apabila mengklik item proyek lalu menekan tombol Delete maka data proyek akan terhapus, seperti yang tertera pada gambar berikut :

Sistem Informasi Penjadwalan dan Pengendalian Biaya Proyek Konstruksi 


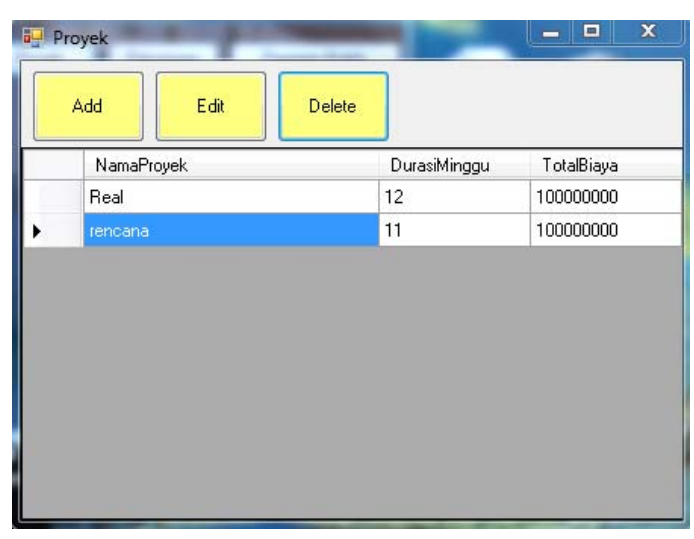

Gambar 9 Sebelum Dihapus.

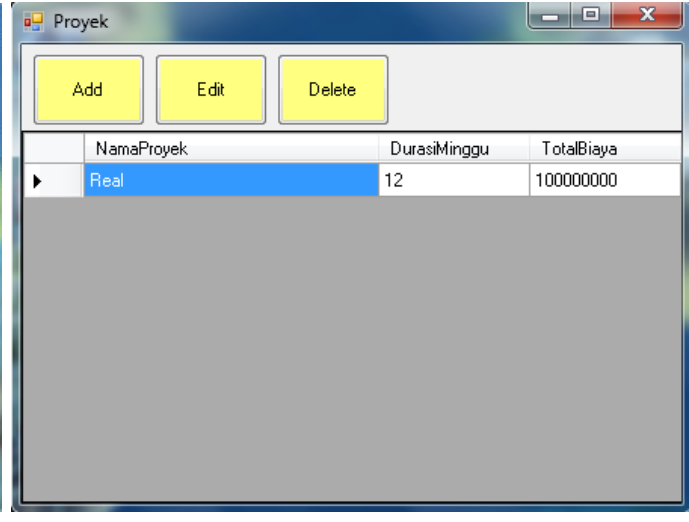

Gambar 10 Setelah Dihapus.

\subsection{Form Pekerjaan}

Form Pekerjaan akan terbuka setelah mengklik tombol pekerjaan. Form ini berisi listbox proyek, tombol Add, tombol Edit, dan tombol Delete, serta tabel pekerjaan yang berisi Pekerjaan, Durasi_Minggu, BergantungPada, HargaSatuan, MulaiPada, dan Bobot_Persen.

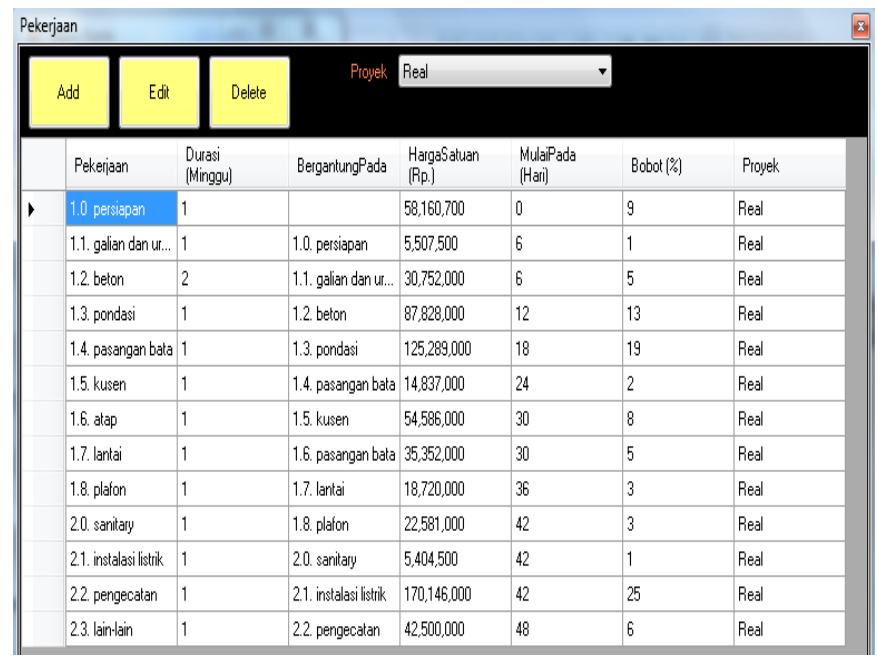

\section{Gambar 11 Form Pekerjaan.}

\subsubsection{List Box Proyek}

ListBox ini untuk membedakan jenis proyek yang digunakan, misalnya untuk membedakan proyek nyata berdasarkan kejadian yang terjadi pada lapangan dan proyek rencana yang kita rencanakan sebelumnya 


\subsubsection{Tombol Add}

Apabila tombol Add ditekan maka akan muncul group box untuk menginput data-data pekerjaan, seperti yang tertera pada gambar berikut :

\begin{tabular}{|c|c|c|c|c|c|c|c|}
\hline \multicolumn{8}{|c|}{ Pekerjaan } \\
\hline & Edit & Delete & \multicolumn{2}{|c|}{ Proyek Real } & & 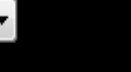 & \\
\hline & Pekerjaan & $\begin{array}{l}\text { Durasi } \\
\text { (Minggu) }\end{array}$ & \multirow{2}{*}{ Pekeriaan } & & & Bobot $(\%)$ & Proyek \\
\hline & 1.0 persiapan & 1 & & 2.4. ekstra & & 9 & Real \\
\hline & 1.1. galian dan ur... & 1 & Durasi Minggu & & & 1 & Real \\
\hline & 1.2. beton & 2 & \multirow{2}{*}{$\begin{array}{l}\text { Bergantung Pada } \\
\text { Harga Satuan (Rp.] }\end{array}$} & 2.3. Lain-lain & & 5 & Real \\
\hline & 1.3. pondasi & 1 & & $5,000,000$ & & 13 & Real \\
\hline & 1.4. pasangan bata & 1 & \multirow{2}{*}{ Mulai Pada (Hari ke) } & & & 19 & Real \\
\hline & 1.5. kusen & 1 & & & & 2 & Real \\
\hline & 1.6. atap & 1 & \multirow{3}{*}{ Bobot (\%) } & & & 8 & Real \\
\hline & 1.7. lantai & 1 & & Add & ide & 5 & Real \\
\hline & 1.8. plafon & 1 & & & & 3 & Real \\
\hline & 2.0. sanitary & 1 & 1.8. plafon & $22,581,000$ & 42 & 3 & Real \\
\hline & 2.1. instalasi listrik & 1 & 2.0. sanitary & $5,404,500$ & 42 & 1 & Real \\
\hline & 2.2. pengecatan & 1 & 2.1. instalasi listrik & $170,146,000$ & 42 & 25 & Real \\
\hline 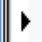 & 2.3. Lain-lain & 1 & 2.2. pengecatan & $10,000,000$ & 48 & 1 & Real \\
\hline
\end{tabular}

Gambar 12 Group Box Add.

Pada Group Box Add ini dapat dilakukan penginputan data pekerjaan, antara lain data Pekerjaan, Durasi Bulan, Bergantung Pada, Harga Satuan, Mulai Pada(Hari ke), dan Bobot(\%). Selain itu terdapat pula tombol Add dan tombol Hide. Tombol Add berfungsi untuk menambahkan data dan menyimpannya ke database. Tombol Hide berfungsi untuk menutup group box.

\subsubsection{Tombol Edit}

Apabila tombol Edit ditekan maka akan muncul group box untuk mengedit datadata pekerjaan, seperti yang tertera pada gambar berikut : 


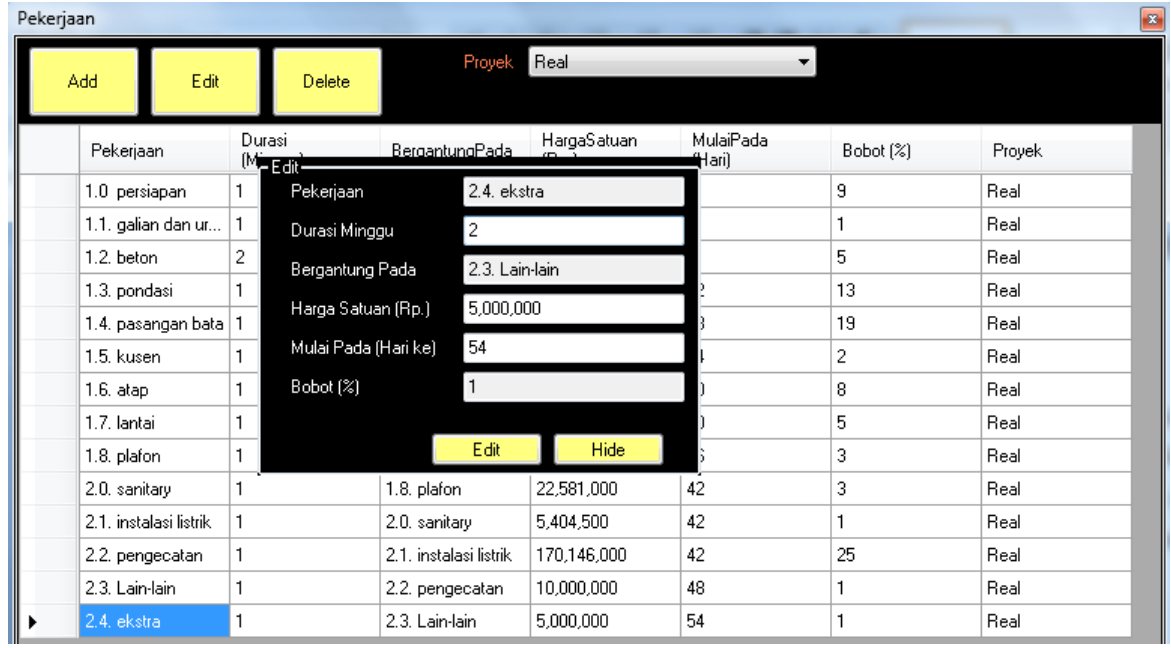

Gambar 13 Group Box Edit.

Pada Group Box Edit ini dapat dilakukan pengubahan data pekerjaan yang telah diinput, antara lain data Pekerjaan, Durasi Bulan, Bergantung Pada, Harga Satuan, Mulai Pada(Hari ke), dan Bobot(\%). Selain itu terdapat pula tombol Add dan tombol Hide. Tombol Edit berfungsi untuk mengedit data dan menyimpannya ke database. Tombol Hide berfungsi untuk menutup group box.

\subsubsection{Tombol Delete}

Apabila mengklik item pekerjaan lalu menekan tombol Delete maka data pekerjaan akan terhapus, seperti yang tertera pada gambar berikut :

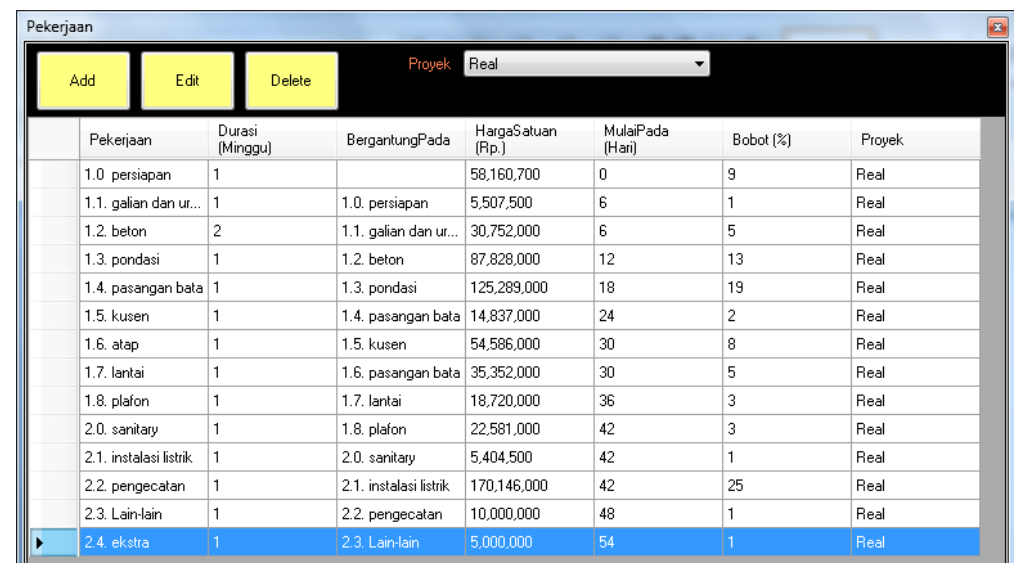

Gambar 14 Proses sebelum dihapus 


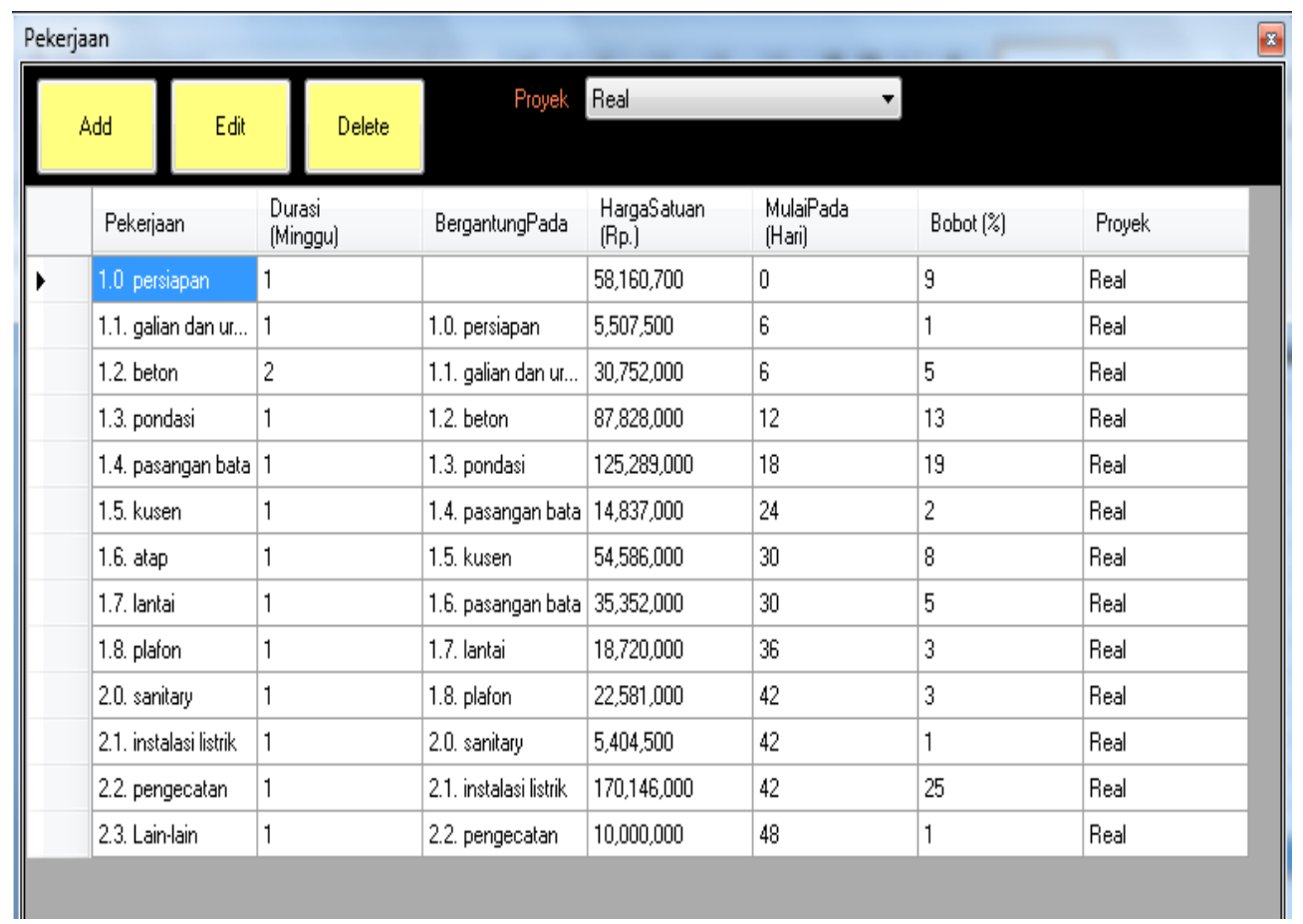

Gambar 15 Proses setelah dihapus.

\subsection{Form Diagram Balok}

Form Diagram Balok akan terbuka setelah mengklik tombol Diagram. Form ini berisi tombol Create, panel untuk membuat diagram balok, dan tabel Data Pekerjaan. Apabila tombol Create diklik maka data yang telah diinput akan dieksekusi sehingga form ini menampilkan diagram balok dan kurva S pada panel yang telah tersedia, seperti gambar berikut :

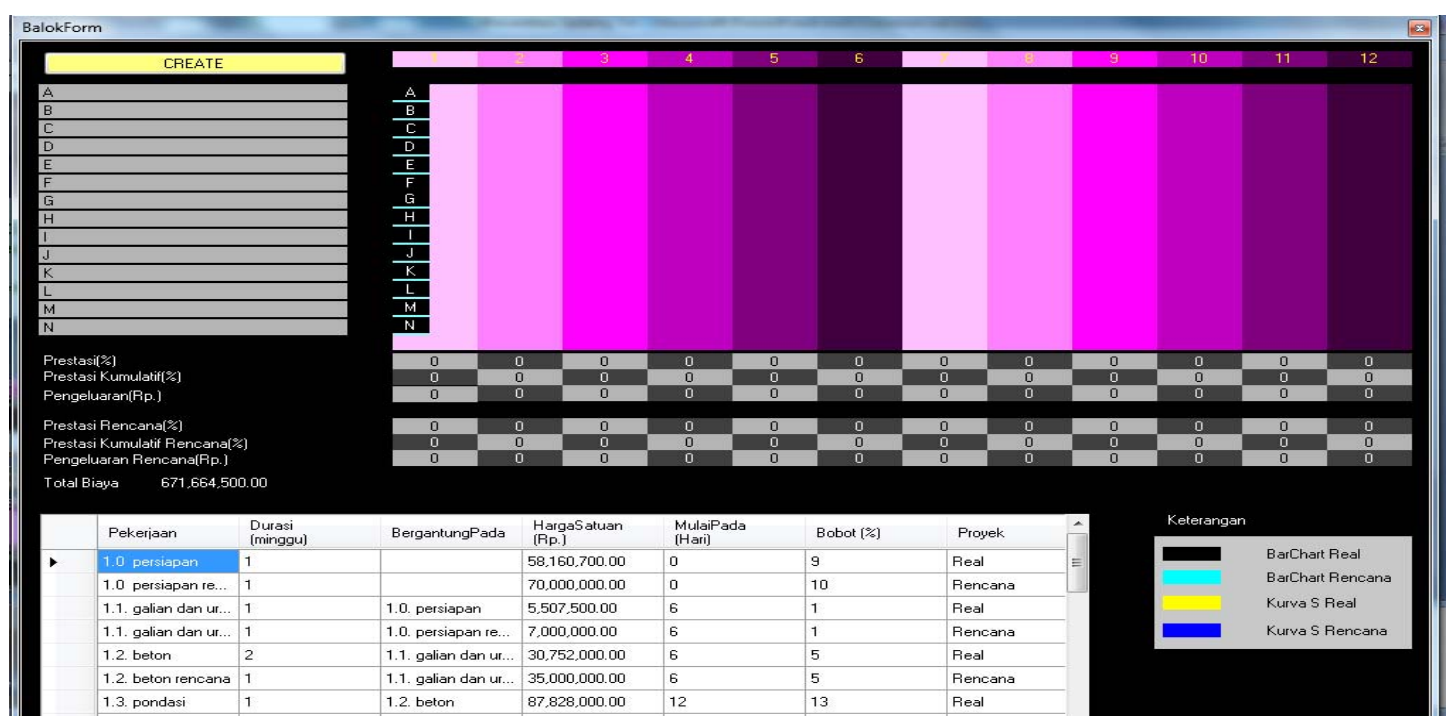

\section{Gambar 16 Sebelum Dieksekusi.}

Sistem Informasi Penjadwalan dan Pengendalian Biaya Proyek Konstruksi 


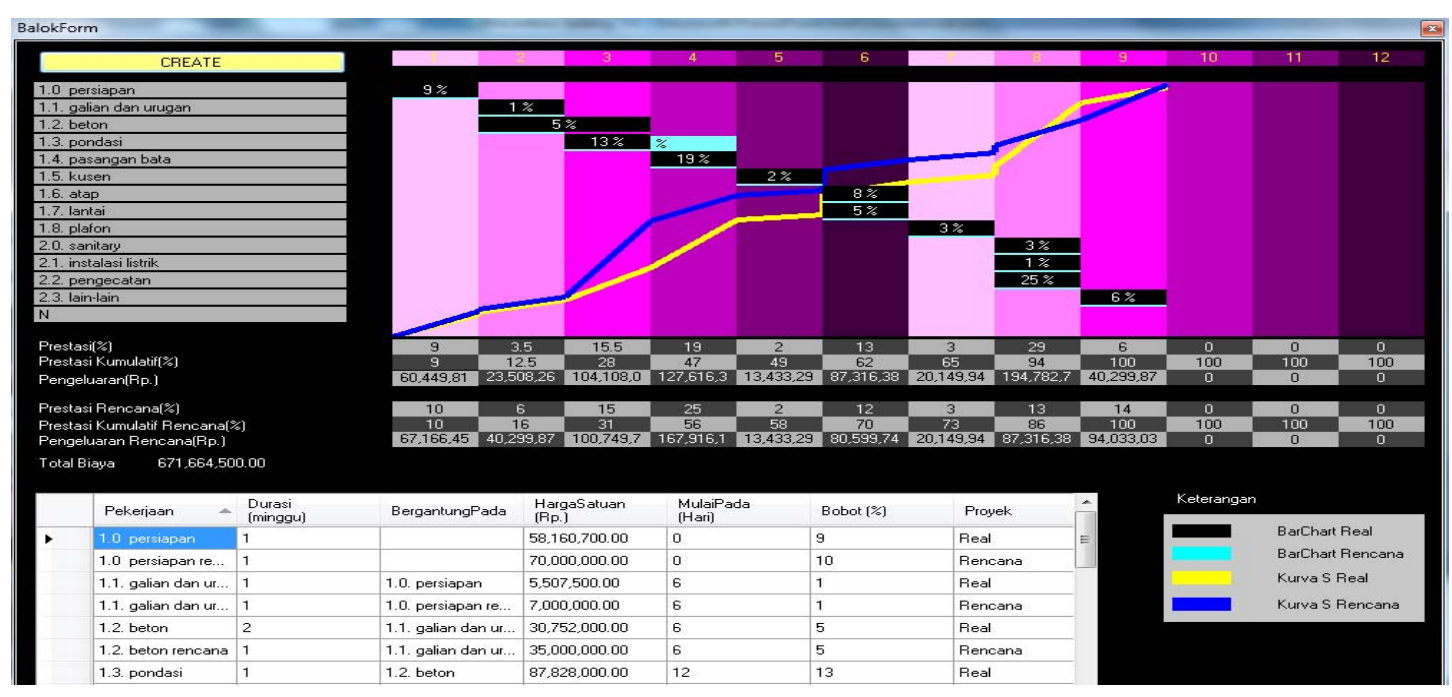

\section{Gambar 17 Setelah Dieksekusi.}

\section{KESIMPULAN DAN SARAN}

\subsection{Kesimpulan}

1. Dalam perencanaan proyek dibutuhkan ketepatan dalam pembuatan jadwal rencana kerja, sehingga proyek dapat selesai sesuai dengan waktu yang ditetapkan.

2. Pengendalian proses konstruksi dan pengeluaran dapat dilakukan dengan membandingkan antara yang direncanakan dengan yang terjadi sesungguhnya.

3. Software sistem informasi penjadwalan dan pengendalian proyek konstruksi bangunan berhasil untuk membuat penjadwalan dan pengendalian proyek dengan menghasilkan Bar Chart dan Kurva S serta perhitungan pengeluaran yang diperlukan setiap minggunya yang dapat membantu dalam proses penjadwalan dan pemantauan pekerjaan konstruksi.

\subsection{Saran}

1. Sebaiknya penjadwalan dan pengendalian proyek dilakukan dengan baik, mengingat bahwa dengan adanya bantuan software belum tentu mengatasi keseluruhan hambatan yang dapat menyebabkan keterlambatan.

2. Software sistem informasi penjadwalan dan pengendalian proyek konstruksi bangunan sekolah sebaiknya dapat dikembangan agar dapat meliputi bidang lainnya dalam suatu pelaksanaan proyek seperti penggambaran chritical path method, perhitungan harga satuan pekerjaan, perhitungan rancangan anggaran biaya, inventory material, serta hal lainnya yang merupakan bagian vital di dalam suatu proyek konstruksi. 


\section{LAMPIRAN}

Catatan :

1. Aplikasi hanya dapat digunakan pada Windows 7.

2. Untuk menggunakan aplikasi pada sistem operasi selain Windows 7 harus dilakukan instalasi Microsoft .NET Framework versi 2.0 , versi 3.0, dan versi 3.5.

Petunjuk penggunaan aplikasi :

Halaman Proyek

1. Hanya dapat diisi oleh 2 proyek, yaitu untuk proyek rencana dan proyek nyata yang terjadi di lapangan.

2. Penginputan durasi maksimum 12 minggu.

\section{Halaman Pekerjaan}

1. Pengurutan pekerjaan dilakukan berdasarkan alphabet, oleh karena itu untuk mempermudah pengurutan sebaiknya nama pekerjaan diawali dengan kode angka.

2. Harga satuan pekerjaan tidak boleh melebihi Total biaya proyek yang diinput pada halaman Proyek.

3. Mulaipada (Hari ke-) akan terisi secara otomatis berdasarkan hasil input bergantung pada. Hasil perhitungan otomatis Mulaipada (Hari ke-) dapat diubah apabila hasil perhitungan tidak sesuai keinginan.

4. Bobot akan terhitung otomatis berdasarkan Harga satuan dan Total biaya proyek. Hasil perhitungan yang dihasilkan berupa angka bulat (tanpa desimal).

\section{DAFTAR PUSTAKA}

1. Tanubrata, Maksum, Ir., MT, "Diktat Kuliah Manajemen Rekayasa Konstruksi“, Universitas Kristen Maranatha Bandung.

2. Husen, Abrar, Ir., MT, “ Manajemen Proyek “, Penerbit ANDI Yogyakarta. 